\title{
Understanding of type 1 diabetes mellitus: what we know and where we go
}

\author{
Chong Kun Cheon, MD, PhD \\ Department of Pediatrics, Pusan National University School of Medicine, Yangsan, Korea
}

The incidence of type 1 diabetes mellitus (T1DM) in children and adolescents is increasing worldwide. Combined effects of genetic and environmental factors cause T1DM, which make it difficult to predict whether an individual will inherit the disease. Due to the level of self-care necessary in T1DM maintenance, it is crucial for pediatric settings to support achieving optimal glucose control, especially when adolescents are beginning to take more responsibility for their own health. Innovative insulin delivery systems, such as continuous subcutaneous insulin infusion (CSII), and noninvasive glucose monitoring systems, such as continuous glucose monitoring (CGM), allow patients with T1DM to achieve a normal and flexible lifestyle. However, there are still challenges in achieving optimal glucose control despite advanced technology in T1DM administration. In this article, disease prediction and current management of T1DM are reviewed with special emphasis on biomarkers of pancreatic $\beta$-cell stress, CSII, glucose monitoring, and several other adjunctive therapies.

Key words: Type 1 diabetes mellitus, Biomarkers, Glucose monitoring, Glucose control

\section{Introduction}

Type 1 diabetes mellitus (T1DM) is a disease characterized by decreased insulin secretion or complete insulin deficiency due to autoimmune beta-cell dysfunction, and it occurs mostly in children and adolescent populations. ${ }^{1)}$ The risk of complications in T1DM can be managed through intensive glucose control, which sometimes leads to undesirable adverse effects (AEs), including increased risk of weight gain, hypoglycemia, higher insulin doses, and frequent injections. ${ }^{2)}$ Although insulin medication and glucose monitoring have advanced, patients with T1DM experience difficulties in reaching their target glucose control goals. As a result, studies have been conducted on clinical evidence of adjunctive therapies to insulin therapy in T1DM. Along with this, identification of promising $\beta$-cell specific biomarkers is becoming a reality, owing to leading-edge technology. In this article, the current understanding of disease prediction and management of T1DM are reviewed with special emphasis on the following: biomarkers of pancreatic $\beta$-cell stress, potential role of continuous subcutaneous insulin infusion (CSII), continuous glucose monitoring (CGM), and several adjunctive therapy.

\section{Incidence of T1DM in Korea}

The frequency of T1DM varies depending upon geography, age, sex, family history, and ethnicity. In Europe, Australia, and the Middle East, rates of T1DM are up by 2\%-5\% per year. $^{3-5)}$ In a retrospective cohort study in southern part of Korea from 2001 to 2010, the average approximate incidence rate of T1DM was 2.01/100,000. ${ }^{6)}$ The reported incidence of
Corresponding author: Chong Kun Cheon, MD, $\mathrm{PhD}$

Department of Pediatrics, Pusan National University Children's Hospital, Pusan National University School of Medicine, 20 Geumo-ro, Mulgeum-eup, Yangsan 50612, Korea

Tel: $+82-55-360-3158$

Fax: +82-55-360-2181

E-mail: chongkun@pusan.ac.kr https://orcid.org/0000-0002-8609-5826

Received: 17 August 2018

Revised: 23 September 2018

Accepted: 4 October 2018
Copyright (C) 2018 by The Korean Pediatric Society

This is an open-access article distributed under the terms of the Creative Commons Attribution NonCommercial License (http://creativecommons.org/ licenses/by-nc/4.0/) which permits unrestricted noncommercial use, distribution, and reproduction in any medium, provided the original work is properly cited. 
T1DM in Korean children and adolescents from 2012 to 2014 was $3.19 / 100,000$. $^{7}$

\section{Genetic factors for T1DM}

To date, more than twenty regions of the genome recognized as predisposing factors for T1DM have been recognized; however, only two (human leukocyte antigen [HLA] region, insulin gene region) of them have shown strong evidence in association with the disease. ${ }^{8,9)}$ HLA genes are well known for their polymorphisms and great variability, such that no specific mutation has been identified as a direct cause of T1DM. ${ }^{10)}$ Approximately $40 \%$ of the genetic risk associated with T1DM is related to the HLA region class II, especially HLA-DR and HLA-DQ, where haplotypes with the greatest association are DRB1 * 0401 or * 0405 and DQB1 * 0301 (DR4-DQ8). ${ }^{11)}$ However, less than $20 \%$ of cases are related to major histocompatibility complex class I mutations, in which haplotypes HLAB * 3906 or HLA-A * 2402 set susceptibility towards T1DM. ${ }^{10)}$

\section{Environmental risk factors for T1DM}

Epidemiologic studies suggest that environmental factors play a leading role in the development of T1DM in activating the disease. ${ }^{12)}$ These factors include cow milk protein, ${ }^{13)}$ vitamin D, viral infections, and limited exposure to microorganisms during childhood. ${ }^{14)}$

\section{Study of vitamin D}

Vitamin D can shift the balance of the body's T-cell response toward downregulation of the T-helper-1 immune response. ${ }^{15)}$ In particular, vitamin D and T1DM vitamin D receptor (VDR) have been considered to play a role in the pathogenesis of T1DM. In 2015, Cheon et al. ${ }^{16)}$ conducted a study about the contribution of VDR polymorphisms to T1DM susceptibility in a genetically homogenous population in Korea. It was suggested that T and b TaqI and BsmI alleles might be protective against T1DM in Korean subjects. A meta-analysis performed by Qin et al. ${ }^{17)}$ revealed that the VDR BsmI $B$ allele, bb genotype was closely connected with T1DM risk in Asians, while the bb genotype was linked to T1DM risk in overall populations. There has been skepticism about the effect of vitamin D supplementation as a preventative measure of T1DM. A Norwegian study reported that higher serum 25-hydroxyvitamin D during late pregnancy was related to lower risk of T1DM in the offspring, ${ }^{18)}$ but a Finnish study revealed that there was no association between serum concentrations of 25-hydroxyvitamin $\mathrm{D}$ in the first trimester of pregnancy and the risk of T1DM in babies. ${ }^{19)}$ A retrospective meta-analysis research revealed that infants given vitamin D had lower risks than those without supplementation (odds ratio, 0.71). ${ }^{20}$ ) The Diabetes Autoimmunity Study in the Young investigated 25- hydroxyvitamin D concentrations in plasma during infancy and throughout childhood and identified no link to islet autoimmunity or advancement to T1DM. ${ }^{21)}$ However, there is limited supporting evidence from prospective birth cohort studies despite interest in vitamin D supplementation to prevent islet autoimmunity and T1DM.

\section{Study of cow's milk}

Most prospective birth cohort studies have not proven association between early exposure to cows' milk and either islet autoimmunity or T1DM. ${ }^{22-24)}$ In a double-blind, randomized trial, among 230 infants at risk of T1DM, those given a casein hydrolysate formula showed relatively lower risk of islet autoimmunity than those receiving cow's milk-based formula during the first 6 to 8 months. ${ }^{25}$ ) However, this effect on islet autoimmunity was not confirmed in the larger phase 3 study. ${ }^{26)}$ Cow's milk ingestion in childhood has been related to both increased risk of islet autoimmunity ${ }^{27,28)}$ and T1DM. ${ }^{29,30)}$ Higher intake of cow's milk might boost advancement to T1DM among children with islet autoimmunity, ${ }^{13)}$ which could be mediated by a portion of certain fatty acids in cow's milk and meats. ${ }^{31)}$ This result could promote a new modality of dietary interventions to stave off T1DM when confirmed by further studies.

\section{Study of intestinal microbiota}

Some environmental factors of T1DM are interconnected with the human microbiome. Gut microbes affect glucose and lipid metabolism, immunity, and systemic inflammation outside of the intestines. ${ }^{32-34)}$ T1DM risk might be modulated by commensal microbiota, ${ }^{32,35)}$ but research has been limited. Some have reported lower microbial diversity in children with islet autoimmunity prior to diabetes progression, compared with a healthy control group. ${ }^{35,36)}$ Larger studies with carefully selected controls are needed using nextgeneration sequencing of the microbiome at multiple time-points.

\section{Study of infections}

Recent findings have shown that enteroviral VP1 protein immunoreactivity in the $\beta$ cells of children with T1DM was more frequently detected than in controls. ${ }^{37,38)}$ In an in vitro study, it was proposed that continuous enteroviral infection of human pancreatic ductal cells might lessen their ability to transdifferentiate into $\beta$ cells, thus causing $\beta$-cell mass reduction owing to autoimmunity. ${ }^{39)}$

\section{Biomarkers of pancreatic $\beta$-cell stress and death in T1DM}

Studies have been conducted to identify circulating biomarkers that dictate islet $\beta$-cell stress and death, which could be used to recognize individuals at risk of developing T1DM before the onset of $\beta$-cell destruction. ${ }^{40)}$ In practice, finding $\beta$-cell biomarkers 
has been challenging because $\beta$-cells represent a small fraction $(\leq 1 \%)$ of the total pancreatic mass. ${ }^{41)}$ However, separation and identification of $\beta$-cell specific/selective biomarkers are becoming available to researchers through advanced sequencing technologies and methodologies. ${ }^{40)}$ The Belgian Diabetes Registry showed that autoantibody-positive first-degree relatives with random circulating proinsulin/C-peptide (PI/C) ratios above the 66th percentile had an increased risk of T1DM development in 5 years. ${ }^{42)}$ Recently, it was reported that fasting PI/C ratios within an international cohort of autoantibody-positive family members of individuals with T1DM were significantly higher up to 12 months before the onset of T1DM. ${ }^{43)}$ Several micro-RNAs (miRNAs) have been also suggested as biomarkers in patients with T1DM. In-depth sequencing of human islets and isolated $\beta$-cells has identified several miRNAs, including miRNA-25, with relative enrichment in $\beta$-cells. ${ }^{44}$ One of the most abundant miRNAs in $\beta$-cells, miRNA-375, inhibited glucosestimulated insulin secretion, and it was increased in serum after allogeneic and autologous islet transplantation. ${ }^{45}$ Further, there have been other potential miRNAs elevated in the serum of patients with recent-onset T1DM. ${ }^{44)}$ One notably potential approach for biomarker advancement has been the identification of differentially methylated DNA fragments. ${ }^{40)}$ Due to the nearly exclusive manner of gene expression of multiple genes in the islet $\beta$-cell, it can translate to potential regulation by selective DNA methylation. ${ }^{40)} \mathrm{In}$ islets and $\beta$-cells, human and mouse genes have been known to be hypomethylated at selective $\mathrm{CpG}$ sites in the coding and promoter regions, ${ }^{46}$ and human INS expression is reversely connected with methylation at many of these sites in human islets (Table 1). ${ }^{47)}$

\section{CGM in T1DM}

It is evident that use of CGM can dramatically improve the quality of glycemic control in T1DM in comparison to self-monitoring of blood glucose $\left.(\mathrm{SMBG}){ }^{48}\right)$ The benefit is especially notable in high-risk individuals with frequent or severe hypoglycemia, often associated with hypoglycemia unawareness. ${ }^{48)} \mathrm{GM}$ can be used effectively with either multiple daily injections (MDI) or with CSII. ${ }^{49-51)}$

\section{Approval for nonadjunctive use}

Currently, CGM is approved by the FDA in the outpatient setting as an ancillary instrument, which allows for an increase in information obtained from standard home blood glucose monitoring devices and aids in the recognition of hypoglycemic and hyperglycemic events. ${ }^{52)}$ The initial approval was given to only one model, the Dexcom G5 sensor. ${ }^{48)}$ Many CGM users have already found that the CGM provides sufficient information, accuracy, and reliability for insulin dosage adjustments based on the CGM alone. ${ }^{48,51,53)}$

\section{Efficacy of CGM in conjunction with MDI or CSII}

Most of the early studies with CGM were conducted on people with T1DM who were also using a CSII. There were questions as to whether similar benefits would be seen in people using basalbolus therapy with MDI. There is now considerable evidence that improvements in the quality of glycemic control are essentially identical in MDI and CSII users. ${ }^{49-51)}$ The effectiveness of CGM for people with T1DM using MDI as well as CSII was clearly described in recent randomized clinical trials showing that changes in mean glucose were equivalent for users of MDI and CGM. ${ }^{49,50,54)}$

\section{CGM use in high-risk patients for hypoglycemia}

A recent clinical trial assessed the performance of CGM for patients at high risk to experience hypoglycemia. Van Beers et al. ${ }^{51)}$ conducted a crossover randomized study and demonstrated a dramatic increase in percentage of time in the target range, which was identical for MDI or CSII users, with an accompanying marked reduction in the hypoglycemia frequency.

\section{CGM studies in hospitalized patients}

CGM usage in the inpatient setting and ICU remains a work in progress. ${ }^{5,56)}$ There has been considerable interest in using CGM in the hospitalized patients for glycemic control, in particular for patients continuing use of outpatient therapies, for control of insulin infusions, and for use in the intensive care unit. ${ }^{48)}$ Continuous improvements in the accuracy, robustness, and usability of CGM sensors offer a promising outlook for their role in the inpatient setting. ${ }^{48)}$ Thabit et al. ${ }^{57)}$ have recently reported substantial improvements in glucose control in a randomized parallel-arm study of 40 inpatients with type $2 \mathrm{DM}$ using a closed-loop control without premeal boluses.

Table 1. Summary of candidate biomarkers to monitor $\beta$-cell stress and death in T1DM

\begin{tabular}{|c|c|c|}
\hline Candidate biomarker & Results from patients with T1DM & Source \\
\hline \multirow[t]{2}{*}{$\mathrm{PI} / \mathrm{C}$ ratio } & Increased PI/C ratio in autoantibody-positive patients who progressed to T1DM & Schopman et al. $(2015)^{69)}$ \\
\hline & Increased $\mathrm{PI} / \mathrm{C}$ ratio was a predictor of T1DM onset & Sims et al. $(2016)^{43)}$ \\
\hline miRNA-375 & Increased miRNA-375 in serum after autologous/allogeneic islet transplantation & Kanak et al. $(2015)^{45)}$ \\
\hline miRNA-152, miRNA-30a-5p, miRNA-181a & Increased in serum in patients with recent-onset T1DM & Nielsen et al. $(2012)^{44)}$ \\
\hline unmethylated INS DNA & Increased in patients receiving allogeneic islet transplantation & Husseiny et al. (2014) ${ }^{46)}$ \\
\hline
\end{tabular}

$\mathrm{PI} / \mathrm{C}$, proinsulin/C-peptide; INS, insulin gene; miRNA, micro-RNA; T1DM, type 1 diabetes mellitus. 
Specifically, the proportion of time in the target range increased from $38.1 \%$ in the control group to $59.8 \%$, a $21.8 \%$ change. In practice, there are safety concerns regarding data analysis. Occasionally, inexperienced experts might make hasty or inappropriate decisions about doses because of the enormity of data output. Further studies are recommended to provide sufficient information about the possible benefits of CGM for hospitalized patients (Table 2). Since CGMs are often used along with insulin pumps, guidelines should be established for both technologies in hospitalized patients.

\section{Use and efficacy of CSII in T1DM}

Currently, pediatric patients with T1DM are frequently treated with CSII. A meta-analysis conducted by Kaiserman et al ${ }^{58)}$ included 26 studies of more than 2,500 pediatric and adolescent patients with T1DM. Within the randomized controlled trials (RCTs) comparing insulin lispro CSII with MDI, glycosylated hemoglobin $\left(\mathrm{HbA}_{1 \mathrm{c}}\right)$ levels achieved with insulin lispro were similar to or better than observations with the MDI treatment arm. In the RCTs, insulin lispro CSII and MDI therapy showed comparable incidences of diabetic ketoacidosis and severe hypoglycemia. The Agency for Healthcare Research and Quality systematic review of RCTs concluded that both insulin delivery modalities (CSII and MDI) display similar effectiveness on glycemic control and severe hypoglycemia in pediatric patients with T1DM. ${ }^{59)}$ In children and adults with T1DM, CSII improves quality of life greater than MDI, albeit with low strength of evidence. In supplementary findings, it was shown that the use of sensor-augmented insulin pumps (real time-CSII+CGM) was superior to MDI/SMBG in lowering HbA1c in patients with T1DM. ${ }^{59)}$ Recently, Ruiz-de-Adana et al. ${ }^{60)}$ performed a randomized study including 45 patients with T1DM (mean $\mathrm{HbA}_{1 \mathrm{c}}, 8.6 \% \pm 1.8 \%$ ). Significant improvements were demonstrated in the $\mathrm{HbA}_{1 \mathrm{c}}(7.9 \% \pm 0.7 \%$ vs. $7.0 \% \pm 0.6 \%, P<0.001)$ and quality of life in the CSII group after 6 months. $\mathrm{HbA}_{1 \mathrm{c}}$ levels of the CSII group were lower than the MDI/ glargine group (CSII 7.0\% $\pm 0.6 \%$ vs. MDI/G 7.6\% $\pm 0.9 \%, P<0.03$ ).

\section{Adjunctive therapies to insulin therapy in T1DM}

Although insulin technology and its administration have shown remarkable advances, individuals with T1DM have continued difficulties in maintaining target glucose levels and sometimes suffer $\mathrm{AE}$, such as severe hypoglycemia and weight gain. ${ }^{61)}$ Therefore, the evaluation of adjunctive therapies in individuals with T1DM is required.

\section{Metformin as T1DM treatment}

Metformin lowers hepatic glucose production, reduces glucose absorption in the intestines, and fosters glucose uptake and insulin sensitivity in peripheral tissues, resulting in a reduction of fasting and postprandial glucose. ${ }^{61)}$ Several clinical studies have been conducted for metformin therapy in T1DM pediatric patients (Table 3). Hamilton et $\mathrm{al}^{62)}$ examined pediatric patients $(\mathrm{n}=27)$ with T1DM who required insulin doses $>1$ unit/kg/day. HbA1c was lower by up to $0.6 \%$ in the metformin group than in the placebo group. Fasting plasma glucose (FPG) was significantly reduced with metformin $(-21.6 \pm 36 \mathrm{mg} / \mathrm{dL}$ vs. $1.8 \pm 45 \mathrm{mg} / \mathrm{dL}, P=0.004)$. Insulin doses were notably lower in the metformin group $(-0.14 \pm 0.1$ units $/ \mathrm{kg} /$ day vs. $0.02 \pm 0.2$ units $/ \mathrm{kg} /$ day, $P<0.01)$. It was observed that body mass index (BMI) was lower in the metformin group, but it was not significant. In another clinical trial, 30 adolescent patients were randomly given metformin or placebo for three months. $\mathrm{HbA}_{1 \mathrm{c}}$ level significantly decreased $(9.6 \%$ to $8.7 \%$ ) in the metformin group, but it did not change in the placebo group. Individuals having lower insulin sensitivity showed greatest benefit from metformin therapy. ${ }^{63)}$ A randomized, double-blinded placebo-controlled study examined adolescent patients $(n=74)$ with T1DM for 6 months. ${ }^{64)}$ They were randomized to either metformin $500 \mathrm{mg}$ twice daily or placebo. Overweight or obese patients with metformin showed a trend toward lower $\mathrm{HbA}_{1 \mathrm{c}}$. Daily insulin dose (DID) in units and units/kg was significantly reduced by metformin. Further, metformin dramatically decreased BMI $z$ scores. To assess metformin added to insulin therapy in overweight or obese patients with T1DM, 2 RCTs were conducted. In the first trial of enrolled patients ( $\mathrm{n}=140$, aged $12-20$ years), ${ }^{65)} \mathrm{HbA}_{1 \mathrm{c}}$ dropped significantly around 3 months, but it was not maintained around 6 months. Mean total DID per kg was lower in the metformin group than the placebo

Table 2. Further studies required for continuous glucose monitoring (CGM) in inpatient setting

\begin{tabular}{ll}
\hline Number & \\
\hline 1 & Research of long term clinical results (e.g., hospitalization period, hospital acquired infection rates, and inpatient mortality) \\
3 & Researches on latent disturbance on CGM use (e.g., dehydration, hypoxemia/hyperthermia, vasoconstriction/vasodilatation, and edema). \\
4 & Cost studies of CGM to the hospital, its effects on nursing workload \\
5 & Data processing algorithm researches incorporating CGM. \\
6 & Adverse/safety researches demonstrating institutional models of device use in the hospital \\
7 & Event investigation and analysis of patient reporting process \\
8 & Research on clinical practice model of nursing documentation and education \\
\hline
\end{tabular}


Table 3. Summary of clinical trials with metformin in type 1 diabetes mellitus

\begin{tabular}{|c|c|c|c|c|c|c|c|c|}
\hline Source & $\begin{array}{l}\text { No. of patients } \\
\text { enrolled }\end{array}$ & Study design & $\begin{array}{l}\text { Study } \\
\text { periods } \\
\text { (wk) }\end{array}$ & Groups treated & $\begin{array}{c}\text { Duration of } \\
\text { diabetes } \\
(\mathrm{yr})^{\star}\end{array}$ & $\begin{array}{c}\text { Change in } \\
\text { insulin dose } \\
\text { (units/kg/day) }^{\dagger}\end{array}$ & $\begin{array}{l}\text { Change in } \\
\mathrm{HbA}_{1 \mathrm{c}}(\%)^{\dagger}\end{array}$ & $\begin{array}{c}\text { Change in } \mathrm{BMl} \\
\left(z \text { score or } \mathrm{kg} / \mathrm{m}^{2}\right)^{\dagger}\end{array}$ \\
\hline \multirow[t]{2}{*}{$\begin{array}{l}\text { Hamilton et al. } \\
(2003)^{62)}\end{array}$} & \multirow[t]{2}{*}{27 Adolescent } & \multirow[t]{2}{*}{$\begin{array}{l}\text { Randomized, } \\
\text { placebo-controlled }\end{array}$} & \multirow[t]{2}{*}{12} & $\begin{array}{l}\text { Metformin (1,000, 1,500 or } \\
2,000 \mathrm{mg} \text { daily) }\end{array}$ & & Delta -0.14 & Delta -0.30 & Delta -0.05 (z score) \\
\hline & & & & Placebo & $9.9 \pm 4.4$ & Delta 0.02 & Delta 0.30 & Delta 0.20 (z score) \\
\hline \multirow[t]{2}{*}{$\begin{array}{l}\text { Särnblad et al. } \\
(2003)^{63)}\end{array}$} & \multirow[t]{2}{*}{26 Adolescent } & \multirow{2}{*}{$\begin{array}{l}\text { Double-blind, } \\
\text { placebo-controlled } \\
\text { trial }\end{array}$} & \multirow[t]{2}{*}{12} & $\begin{array}{l}\text { Metformin (1,000 mg twice } \\
\text { daily) }\end{array}$ & & Delta 0.00 & Delta -0.90 & Delta $-0.20\left(\mathrm{~kg} / \mathrm{m}^{2}\right)$ \\
\hline & & & & Placebo & $7.1 \pm 3.0$ & Delta 0.10 & Delta -0.30 & Delta $-0.60\left(\mathrm{~kg} / \mathrm{m}^{2}\right)$ \\
\hline \multirow[t]{2}{*}{$\begin{array}{l}\text { Nadeau et al. } \\
(2015)^{64)}\end{array}$} & \multirow[t]{2}{*}{$\begin{array}{l}74 \text { Pubertal } \\
\text { adolescents }\end{array}$} & \multirow{2}{*}{$\begin{array}{l}\text { Randomized, double- } \\
\text { blind, placebo- } \\
\text { controlled study }\end{array}$} & \multirow[t]{2}{*}{24} & $\begin{array}{l}\text { Metformin (500 mg twice } \\
\text { daily) }\end{array}$ & $\mathrm{N} / \mathrm{A}$ & Delta -0.09 & Delta -0.30 & Delta -0.07 (z score) \\
\hline & & & & Placebo & $\mathrm{N} / \mathrm{A}$ & Delta 0.01 & Delta 0.20 & Delta 0.07 (z score) \\
\hline \multirow[t]{2}{*}{$\begin{array}{l}\text { Libman et al. } \\
(2015)^{65)}\end{array}$} & \multirow[t]{2}{*}{140 Adolescents } & \multirow[t]{2}{*}{$\begin{array}{l}\text { Randomized clinical } \\
\text { trial }\end{array}$} & \multirow[t]{2}{*}{26} & $\begin{array}{l}\text { Metformin (1,000 mg twice } \\
\text { daily) }\end{array}$ & \multirow[t]{2}{*}{$7.0 \pm 3.3$} & Delta -1.20 & Delta 0.10 & Delta $0.00\left(\mathrm{~kg} / \mathrm{m}^{2}\right)$ \\
\hline & & & & Placebo & & Delta -1.10 & Delta 0.10 & Delta $0.00\left(\mathrm{~kg} / \mathrm{m}^{2}\right)$ \\
\hline $\begin{array}{l}\text { Nwosu et al. } \\
(2015)^{66)}\end{array}$ & 28 Adolescents & $\begin{array}{l}\text { Randomized, double- } \\
\text { blind, placebo- } \\
\text { controlled trial }\end{array}$ & 36 & $\begin{array}{l}\text { Metformin (1,000 mg daily) } \\
\text { Placebo }\end{array}$ & $\begin{array}{l}5.7 \pm 4.4 \\
5.7 \pm 5.0\end{array}$ & $\begin{array}{l}\text { Delta } 1.42 \\
\text { Delta } 1.73\end{array}$ & $\begin{array}{l}\text { Delta }-0.72 \\
\text { Delta }-0.45\end{array}$ & $\begin{array}{l}\text { Delta } 0.60 \text { ( } z \text { score) } \\
\text { Delta } 1.10 \text { (z score) }\end{array}$ \\
\hline
\end{tabular}

${ }^{*}$ Values are presented as mean \pm standard deviation. ${ }^{\dagger}$ Values are presented as mean.

$\mathrm{HbA}_{1 \mathrm{c}}$, glycosylated hemoglobin; BMI, body mass index; N/A, not available.

group (-0.1 [-0.2 to -0.0], $P<0.001)$. The metformin and placebo groups showed BMI reductions of at least 10\% from baseline (24\% vs. 7\%, $P=0.01$ ). The second trial included patients ( $\mathrm{n}=28$, aged $10-$ 20 years) with $\mathrm{T} 1 \mathrm{DM},{ }^{66)}$ and there was no significant difference in $\mathrm{HbA1c}$ and FPG levels between the metformin and placebo group for 9 months. The change in total DID was 0.31 units $/ \mathrm{kg}$ between the metformin and placebo group.

\section{DPP-4 inhibitors as T1DM treatment}

Dipeptidyl peptidase-4 (DPP-4) inhibitors, including sitagliptin and vildagliptin, are known to increase GLP-1 and decrease glucagon levels after a meal without interrupting counterregulatory response during hypoglycemia. ${ }^{67-69)}$ In small study, it was observed that sitagliptin therapy for 4 weeks significantly decreased $\mathrm{HbA}_{1 \mathrm{c}}$ levels by $0.2 \%-0.3 \% ;{ }^{70)}$ however, longer study demonstrated no significant reductions. ${ }^{71)}$ Changes in insulin requirements also range from no change ${ }^{67,68)}$ to minimal reductions of $0.05-0.13$ units $/ \mathrm{kg} /$ day; however, larger reductions were seen in postprandial insulin use. ${ }^{70,71)}$ According to a meta-analysis, DPP-4 inhibitors were not beneficial for patients with T1DM because of the limited glucoselowering effect and the risk of severe hypoglycemia. ${ }^{72)}$ Considering the inadequate evidence for decreases in $\mathrm{HbA}_{1 \mathrm{c}}$ levels and reduction of insulin dose, the application of DPP-4 inhibitors in the clinic setting is restricted at present.

\section{SGLT2 (sodium-glucose cotransporter 2 inhibition) inhibitors as T1DM treatment}

SGLT2 inhibitors may contribute to weight reduction in overweight/obese patients with T1DM and decreased glucose levels by blocking SGLT2 in the renal proximal tubule, interrupting glucose reabsorption. ${ }^{73,74)}$ However, evidence on the beneficial effect of
SGLT2 inhibitors as adjunct to insulin treatment in T1DM remains insufficient. A randomized, double-blind study investigated patients $(n=62)$ with T1DM concerning safety. ${ }^{75)}$ The results of efficacy revealed no significant difference between dapagliflozin and placebo in terms of mean glucose level, except reductions in FPG and TDID. Canagliflozin was examined in patients $(\mathrm{n}=351)$ with T1DM by a randomized, double-blind trial (phase 2 study). ${ }^{76)}$ After 18 weeks, the $\mathrm{HbA}_{1 \mathrm{c}}$ level was decreased by $\geq 0.4 \%$; however, body weight change was not observed in patients. Further, an average rate of hypoglycemia was not different among groups.

\section{Conclusions}

Our current understanding about the cause and administration of T1DM is still far from complete, despite technological advances in T1DM. To improve TIDM predictions, new biomarkers are needed that can redefine risk groups and offer insights into the mechanism of disease onset. For the prevention of devastating complications and better management of T1DM, improvements in adjunct therapies are still needed. Future research efforts should be focused on improving disease prediction and the insulin delivery system, overcoming device limitations, and providing additional data to facilitate optimal clinical management.

\section{Conflicts of interest}

No potential conflict of interest relevant to this article was reported. 


\section{References}

1. Standards of Medical Care in Diabetes-2017: Summary of Revisions. Diabetes Care 2017;40(Suppl 1):S4-5.

2. Diabetes Control and Complications Trial (DCCT)/Epidemiology of Diabetes Interventions and Complications (EDIC) Study Research Group. Intensive diabetes treatment and cardiovascular outcomes in type 1 diabetes: the DCCT/EDIC study 30-year follow-up. Diabetes Care 2016;39:686-93.

3. Punnose J, Agarwal MM, El Khadir A, Devadas K, Mugamer IT. Childhood and adolescent diabetes mellitus in Arabs residing in the United Arab Emirates. Diabetes Res Clin Pract 2002;55:29-33.

4. Shaw JE, Sicree RA, Zimmet PZ. Global estimates of the prevalence of diabetes for 2010 and 2030. Diabetes Res Clin Pract 2010;87:4-14.

5. Karvonen M, Viik-Kajander M, Moltchanova E, Libman I, LaPorte R, Tuomilehto J. Incidence of childhood type 1 diabetes worldwide. Diabetes Mondiale (DiaMond) Project Group. Diabetes Care 2000;23: 1516-26.

6. Lee JH, Kim YM, Kwak MJ, Kim SY, Kim HJ, Cheon CK, et al. Incidence trends and associated factors of diabetes mellitus in Korean children and adolescents: a retrospective cohort study in Busan and Gyeongnam. Ann Pediatr Endocrinol Metab 2015;20:206-12.

7. Kim JH, Lee CG, Lee YA, Yang SW, Shin CH. Increasing incidence of type 1 diabetes among Korean children and adolescents: analysis of data from a nationwide registry in Korea. Pediatr Diabetes 2016;17: 519-24.

8. Rojas J, Bermudez V, Palmar J, Martínez MS, Olivar LC, Nava M, et al. Pancreatic beta cell death: novel potential mechanisms in diabetes therapy. J Diabetes Res 2018;2018:9601801.

9. Grant SF, Hakonarson H, Schwartz S. Can the genetics of type 1 and type 2 diabetes shed light on the genetics of latent autoimmune diabetes in adults? Endocr Rev 2010;31:183-93.

10. Mehers KL, Gillespie KM. The genetic basis for type 1 diabetes. Br Med Bull 2008;88:115-29.

11. Steck AK, Rewers MJ. Genetics of type 1 diabetes. Clin Chem 2011; 57:176-85.

12. Bakay M, Pandey R, Hakonarson H. Genes involved in type 1 diabetes: an update. Genes (Basel) 2013;4:499-521.

13. Lamb MM, Miller M, Seifert JA, Frederiksen B, Kroehl M, Rewers M, et al. The effect of childhood cow's milk intake and HLA-DR genotype on risk of islet autoimmunity and type 1 diabetes: the Diabetes Autoimmunity Study in the Young. Pediatr Diabetes 2015;16:31-8.

14. Betts P, Mulligan J, Ward P, Smith B, Wilkin T. Increasing body weight predicts the earlier onset of insulin-dependant diabetes in childhood: testing the 'accelerator hypothesis' (2). Diabet Med 2005; 22:144-51.

15. Rewers M, Ludvigsson J. Environmental risk factors for type $1 \mathrm{di}$ abetes. Lancet 2016;387:2340-8.

16. Cheon CK, Nam HK, Lee KH, Kim SY, Song JS, Kim C. Vitamin D receptor gene polymorphisms and type 1 diabetes mellitus in a Korean population. Pediatr Int 2015;57:870-4.

17. Qin WH, Wang HX, Qiu JL, Huang XB, Huang Y, Wu NR, et al. A meta-analysis of association of vitamin D receptor BsmI gene polymorphism with the risk of type 1 diabetes mellitus. J Recept Signal Transduct Res 2014;34:372-7.

18. Sørensen IM, Joner G, Jenum PA, Eskild A, Torjesen PA, Stene LC. Maternal serum levels of 25-hydroxy-vitamin D during pregnancy and risk of type 1 diabetes in the offspring. Diabetes 2012;61:175-8.

19. Miettinen ME, Reinert L, Kinnunen L, Harjutsalo V, Koskela P, Surcel $\mathrm{HM}$, et al. Serum 25-hydroxyvitamin D level during early pregnancy and type 1 diabetes risk in the offspring. Diabetologia 2012;55:1291-
4.

20. Zipitis CS, Akobeng AK. Vitamin D supplementation in early childhood and risk of type 1 diabetes: a systematic review and metaanalysis. Arch Dis Child 2008;93:512-7.

21. Simpson M, Brady H, Yin X, Seifert J, Barriga K, Hoffman M, et al. No association of vitamin D intake or 25-hydroxyvitamin D levels in childhood with risk of islet autoimmunity and type 1 diabetes: the Diabetes Autoimmunity Study in the Young (DAISY). Diabetologia 2011;54:2779-88.

22. Holmberg H, Wahlberg J, Vaarala O, Ludvigsson J; ABIS Study Group. Short duration of breast-feeding as a risk-factor for beta-cell autoantibodies in 5-year-old children from the general population. $\mathrm{Br}$ J Nutr 2007;97:111-6.

23. Ziegler AG, Schmid S, Huber D, Hummel M, Bonifacio E. Early infant feeding and risk of developing type 1 diabetes-associated autoantibodies. JAMA 2003;290:1721-8.

24. Frederiksen B, Kroehl M, Lamb MM, Seifert J, Barriga K, Eisenbarth GS, et al. Infant exposures and development of type 1 diabetes mellitus: The Diabetes Autoimmunity Study in the Young (DAISY). JAMA Pediatr 2013;167:808-15.

25. Knip M, Virtanen SM, Seppä K, Ilonen J, Savilahti E, Vaarala O, et al. Dietary intervention in infancy and later signs of beta-cell autoimmunity. N Engl J Med 2010;363:1900-8.

26. Knip M, Åkerblom HK, Becker D, Dosch HM, Dupre J, Fraser W, et al. Hydrolyzed infant formula and early $\beta$-cell autoimmunity: a randomized clinical trial. JAMA 2014;311:2279-87.

27. Wahlberg J, Vaarala 0, Ludvigsson J; ABIS-study group. Dietary risk factors for the emergence of type 1 diabetes-related autoantibodies in 21/2 year-old Swedish children. Br J Nutr 2006;95:603-8.

28. Virtanen SM, Nevalainen J, Kronberg-Kippilä C, Ahonen S, Tapanainen $\mathrm{H}$, Uusitalo L, et al. Food consumption and advanced $\beta$ cell autoimmunity in young children with HLA-conferred susceptibility to type 1 diabetes: a nested case-control design. Am J Clin Nutr 2012; 95:471-8.

29. Verge CF, Howard NJ, Irwig L, Simpson JM, Mackerras D, Silink M. Environmental factors in childhood IDDM. A population-based, casecontrol study. Diabetes Care 1994;17:1381-9.

30. Virtanen SM, Läärä E, Hyppönen E, Reijonen H, Räsänen L, Aro A, et al. Cow's milk consumption, HLA-DQB1 genotype, and type 1 diabetes: a nested case-control study of siblings of children with diabetes. Childhood diabetes in Finland study group. Diabetes 2000;49:912-7.

31. Virtanen SM, Niinistö S, Nevalainen J, Salminen I, Takkinen HM, Kääriä S, et al. Serum fatty acids and risk of advanced beta-cell autoimmunity: a nested case-control study among children with HLA-conferred susceptibility to type I diabetes. Eur J Clin Nutr 2010; 64:792-9.

32. Wen L, Ley RE, Volchkov PY, Stranges PB, Avanesyan L, Stonebraker $\mathrm{AC}$, et al. Innate immunity and intestinal microbiota in the development of Type 1 diabetes. Nature 2008;455:1109-13.

33. Maslowski KM, Mackay CR. Diet, gut microbiota and immune responses. Nat Immunol 2011;12:5-9.

34. Arpaia N, Campbell C, Fan X, Dikiy S, van der Veeken J, deRoos P, et al. Metabolites produced by commensal bacteria promote peripheral regulatory T-cell generation. Nature 2013;504:451-5.

35. Brown CT, Davis-Richardson AG, Giongo A, Gano KA, Crabb DB, Mukherjee N, et al. Gut microbiome metagenomics analysis suggests a functional model for the development of autoimmunity for type 1 diabetes. PLoS One 2011;6:e25792.

36. Kostic AD, Gevers D, Siljander H, Vatanen T, Hyötyläinen T, Hämäläinen AM, et al. The dynamics of the human infant gut microbiome in development and in progression toward type 1 diabetes. Cell 
Host Microbe 2015;17:260-73.

37. Richardson SJ, Willcox A, Bone AJ, Foulis AK, Morgan NG. The prevalence of enteroviral capsid protein vp1 immunostaining in pancreatic islets in human type 1 diabetes. Diabetologia 2009;52:114351.

38. Krogvold L, Edwin B, Buanes T, Frisk G, Skog O, Anagandula M, et al. Detection of a low-grade enteroviral infection in the islets of langerhans of living patients newly diagnosed with type 1 diabetes. Diabetes 2015;64:1682-7.

39. Sane F, Caloone D, Gmyr V, Engelmann I, Belaich S, Kerr-Conte J, et al. Coxsackievirus B4 can infect human pancreas ductal cells and persist in ductal-like cell cultures which results in inhibition of Pdx1 expression and disturbed formation of islet-like cell aggregates. Cell Mol Life Sci 2013;70:4169-80.

40. Mirmira RG, Sims EK, Syed F, Evans-Molina C. Biomarkers of $\beta$-Cell stress and death in type 1 diabetes. Curr Diab Rep 2016;16:95.

41. Butler AE, Cao-Minh L, Galasso R, Rizza RA, Corradin A, Cobelli C, et al. Adaptive changes in pancreatic beta cell fractional area and beta cell turnover in human pregnancy. Diabetologia 2010;53:2167-76.

42. Truyen I, De Pauw P, Jørgensen PN, Van Schravendijk C, Ubani O, Decochez K, et al. Proinsulin levels and the proinsulin:c-peptide ratio complement autoantibody measurement for predicting type $1 \mathrm{di}$ abetes. Diabetologia 2005;48:2322-9.

43. Sims EK, Chaudhry Z, Watkins R, Syed F, Blum J, Ouyang F, et al. Elevations in the fasting serum proinsulin-to-C-peptide ratio precede the onset of type 1 diabetes. Diabetes Care 2016;39:1519-26.

44. Nielsen LB, Wang C, Sørensen K, Bang-Berthelsen CH, Hansen L, Andersen ML, et al. Circulating levels of microRNA from children with newly diagnosed type 1 diabetes and healthy controls: evidence that miR-25 associates to residual beta-cell function and glycaemic control during disease progression. Exp Diabetes Res 2012;2012: 896362.

45. Kanak MA, Takita M, Shahbazov R, Lawrence MC, Chung WY, Dennison AR, et al. Evaluation of microRNA375 as a novel biomarker for graft damage in clinical islet transplantation. Transplantation 2015;99:1568-73.

46. Husseiny MI, Kaye A, Zebadua E, Kandeel F, Ferreri K. Tissue-specific methylation of human insulin gene and PCR assay for monitoring beta cell death. PLoS One 2014;9:e94591.

47. Yang BT, Dayeh TA, Kirkpatrick CL, Taneera J, Kumar R, Groop L, et al. Insulin promoter DNA methylation correlates negatively with insulin gene expression and positively with $\mathrm{HbA}(1 \mathrm{c})$ levels in human pancreatic islets. Diabetologia 2011;54:360-7.

48. Rodbard D. Continuous glucose monitoring: a review of recent studies demonstrating improved glycemic outcomes. Diabetes Technol Ther 2017;19(S3):S25-37.

49. Beck RW, Riddlesworth T, Ruedy K, Ahmann A, Bergenstal R, Haller S, et al. Effect of continuous glucose monitoring on glycemic control in adults with type 1 diabetes using insulin injections: the DIAMOND randomized clinical trial. JAMA 2017;317:371-8.

50. Bolinder J, Antuna R, Geelhoed-Duijvestijn P, Kröger J, Weitgasser R. Novel glucose-sensing technology and hypoglycaemia in type 1 diabetes: a multicentre, non-masked, randomised controlled trial. Lancet 2016;388:2254-63.

51. van Beers CA, DeVries JH, Kleijer SJ, Smits MM, Geelhoed-Duijvestijn $\mathrm{PH}$, Kramer MH, et al. Continuous glucose monitoring for patients with type 1 diabetes and impaired awareness of hypoglycaemia (in control): a randomised, open-label, crossover trial. Lancet Diabetes Endocrinol 2016;4:893-902.

52. Edelman SV. Regulation catches up to reality. J Diabetes Sci Technol 2017;11:160-4.

53. Pettus J, Edelman SV. Recommendations for using real-time continu- ous glucose monitoring (rtCGM) data for insulin adjustments in type 1 diabetes. J Diabetes Sci Technol 2017;11:138-47.

54. Lind M, Polonsky W, Hirsch IB, Heise T, Bolinder J, Dahlqvist S, et al. Continuous glucose monitoring vs conventional therapy for glycemic control in adults with type 1 diabetes treated with multiple daily insulin injections: the GOLD randomized clinical trial. JAMA 2017; 317:379-87.

55. Preiser JC, Chase JG, Hovorka R, Joseph JI, Krinsley JS, De Block C, et al. Glucose control in the ICU: a continuing story. J Diabetes Sci Technol 2016;10:1372-81.

56. Wallia A, Umpierrez GE, Nasraway SA, Klonoff DC; PRIDE Investigators. Round table discussion on inpatient use of continuous glucose monitoring at the international hospital diabetes meeting. J Diabetes Sci Technol 2016;10:1174-81.

57. Thabit H, Hartnell S, Allen JM, Lake A, Wilinska ME, Ruan Y, et al. Closed-loop insulin delivery in inpatients with type 2 diabetes: a randomised, parallel-group trial. Lancet Diabetes Endocrinol 2017; 5:117-24.

58. Kaiserman K, Rodriguez H, Stephenson A, Wolka L, Fahrbach JL. Continuous subcutaneous infusion of insulin lispro in children and adolescents with type 1 diabetes mellitus. Endocr Pract 2012;18:41824.

59. Golden SH, Sapir T. Methods for insulin delivery and glucose monitoring in diabetes: summary of a comparative effectiveness review. J Manag Care Pharm 2012;18(6 Suppl):S1-17.

60. Ruiz-de-Adana MS, Dominguez-Lopez ME, Gonzalez-Molero I, Machado A, Martin V, Cardona I, et al. Comparison between a multiple daily insulin injection regimen (basal once-daily glargine plus mealtime lispro) and continuous subcutaneous insulin infusion (lispro) using continuous glucose monitoring in metabolically optimized type 1 diabetes patients: a randomized open-labelled parallel study. Med Clin (Barc) 2016;146:239-46.

61. Harris K, Boland C, Meade L, Battise D. Adjunctive therapy for glucose control in patients with type 1 diabetes. Diabetes Metab Syndr Obes 2018;11:159-73.

62. Hamilton J, Cummings E, Zdravkovic V, Finegood D, Daneman D. Metformin as an adjunct therapy in adolescents with type 1 diabetes and insulin resistance: a randomized controlled trial. Diabetes Care 2003;26:138-43.

63. Särnblad S, Kroon M, Aman J. Metformin as additional therapy in adolescents with poorly controlled type 1 diabetes: randomised placebo-controlled trial with aspects on insulin sensitivity. Eur J Endocrinol 2003;149:323-9.

64. Nadeau KJ, Chow K, Alam S, Lindquist K, Campbell S, McFann K, et al. Effects of low dose metformin in adolescents with type I diabetes mellitus: a randomized, double-blinded placebo-controlled study. Pediatr Diabetes 2015;16:196-203.

65. Libman IM, Miller KM, DiMeglio LA, Bethin KE, Katz ML, Shah A, et al. Effect of metformin added to insulin on glycemic control among overweight/obese adolescents with type 1 diabetes: a randomized clinical trial. JAMA 2015;314:2241-50.

66. Nwosu BU, Maranda L, Cullen K, Greenman L, Fleshman J, McShea N, et al. A randomized, double-blind, placebo-controlled trial of adjunctive metformin therapy in overweight/obese youth with type $1 \mathrm{di}$ abetes. PLoS One 2015;10:e0137525.

67. Farngren J, Persson M, Schweizer A, Foley JE, Ahrén B. Vildagliptin reduces glucagon during hyperglycemia and sustains glucagon counterregulation during hypoglycemia in type 1 diabetes. J Clin Endocrinol Metab 2012;97:3799-806.

68. Garg SK, Moser EG, Bode BW, Klaff LJ, Hiatt WR, Beatson C, et al. Effect of sitagliptin on post-prandial glucagon and GLP-1 levels in patients with type 1 diabetes: investigator-initiated, double-blind, 
randomized, placebo-controlled trial. Endocr Pract 2013;19:19-28.

69. Schopman JE, Hoekstra JB, Frier BM, Ackermans MT, de Sonnaville JJ, Stades AM, et al. Effects of sitagliptin on counter-regulatory and incretin hormones during acute hypoglycaemia in patients with type 1 diabetes: a randomized double-blind placebo-controlled crossover study. Diabetes Obes Metab 2015;17:546-53.

70. Ellis SL, Moser EG, Snell-Bergeon JK, Rodionova AS, Hazenfield RM, Garg SK. Effect of sitagliptin on glucose control in adult patients with Type 1 diabetes: a pilot, double-blind, randomized, crossover trial. Diabet Med 2011;28:1176-81.

71. Giampietro 0, Giampietro C, Bartola LD, Masoni MC, Matteucci E. Sitagliptin as add-on therapy in insulin deficiency: biomarkers of therapeutic efficacy respond differently in type 1 and type 2 diabetes. Drug Des Devel Ther 2013;7:99-104.

72. Guo H, Fang C, Huang Y, Pei Y, Chen L, Hu J. The efficacy and safety of DPP4 inhibitors in patients with type 1 diabetes: a systematic review and meta-analysis. Diabetes Res Clin Pract 2016;121:184-91.
73. Sonne DP, Hemmingsen B. Comment on American Diabetes Association. Standards of medical care in diabetes-2017. Diabetes Care 2017;40(Suppl. 1):S1-S135. Diabetes Care 2017;40:e92-3.

74. Garber AJ, Abrahamson MJ, Barzilay JI, Blonde L, Bloomgarden ZT, Bush MA, et al. Consensus statement by the American Association of Clinical Endocrinologists and American College of Endocrinology on the comprehensive type 2 diabetes management algorithm - 2017 executive summary. Endocr Pract 2017;23:207-38.

75. Henry RR, Rosenstock J, Edelman S, Mudaliar S, Chalamandaris AG, Kasichayanula S, et al. Exploring the potential of the SGLT2 inhibitor dapagliflozin in type 1 diabetes: a randomized, double-blind, placebocontrolled pilot study. Diabetes Care 2015;38:412-9.

76. Henry RR, Thakkar P, Tong C, Polidori D, Alba M. Efficacy and safety of canagliflozin, a sodium-glucose cotransporter 2 inhibitor, as addon to insulin in patients with type 1 diabetes. Diabetes Care 2015;38: 2258-65. 